\title{
ПУБЯІЧНЕ ПРАВО
}

\author{
удк 342.95 DOI: https://doi.org/10.31617/zt.knute.2021(117)11 \\ JEL Classification: D73, D78, K23 \\ ВЕСЕЛОВ Микола \\ E-mail: veselovndl@ukr.net \\ ORCID: 0000-0002-3963-2764 \\ ЄПРИНЦЕВ ПИлИП \\ E-mail:efs8111@ukr.net \\ ORCID: 0000-0002-9790-9564 \\ д. ю. н., доцент, професор кафедри державно-правових \\ дисциплін факультету № 2 \\ Криворізького навчально-наукового інституту \\ Донецького державного університету внутрішніх справ \\ вул. Степана Тільги, 21, м. Кривий Ріг, 50065, Україна \\ к. ю. н., доцент, проректор університету - директор \\ Криворізького навчально-наукового інституту \\ Донецького державного університету внутрішніх справ \\ вул. Степана Тільги, 21, м. Кривий Ріг, 50065, Україна
}

\section{ЕТИЧНІ НОРМИ У ДІЯЛЬНОСТІ СУБ'ЄКТІВ ПУБЛІЧНОЇ СЛУЖБИ}

Зазначено про відсутність в украӥнському законодавстві чіткого визначення та єдиного розуміння поняття «принципу етичної поведінки» суб'єктів публічної служби. Констатовано, що нормативне закріплення етичних норм для різних категорій суб’єктів публічної служби в Україні відбувається здебільшого на підзаконному рівні та має галузевий характер. Установлено, щсо терміни «принцип етичної поведінки» $i$ «правила етичної поведінки» є взаємообумовленими та взаємозалежними, але не тотожними поняттями.

Ключові слова: публічна служба, суб’єкт публічної служби, принципи діяльності, етична поведінка, правила, норми.

Постановка проблеми. Публічна служба - діяльність на державних політичних посадах, у державних колегіальних органах, професійна діяльність суддів, прокурорів, військова служба, альтернативна (невійськова) служба, інша державна служба, патронатна служба в державних органах, служба в органах влади Автономної Республіки Крим, органах місцевого самоврядування [1, ст. 4].

Авторитет «публічних персон», особливо тих, чия діяльність пов'язана з виконанням державних функцій, представництвом інтересів окремої громади на державному або регіональному рівні чи України у міжнародному масштабі, залежить від їхніх висловлювань, рішень,

(C) Веселов М., Єпринцев П., 2021 
дій і поведінки загалом. В умовах оперативного поширення інформації через засоби масової інформації, Інтернет, мобільні додатки дедалі більшої уваги набуває не лише службова діяльність, а й приватне життя таких осіб. Окремі вчинки (зокрема й висловлювання) деяких українських політиків і державних посадовців «кидають тінь» на відповідний державний орган, послаблюють загальний авторитет публічного адміністрування в країні серед населення, створюють негативний імідж для нашої держави в уявленні іноземних політичних партнерів і потенційних інвесторів загалом.

Лише організаційно-правові механізми вдосконалення державної бюрократії не можуть розв'язати всі проблеми, пов'язані з формуванням нового зразку функціонування публічної служби в Україні. Без етичного фундаменту публічної служби правові механізми часто виявляються непрацездатними. Однією з передумов розвитку України в контексті світових геополітичних змін $\epsilon$ нова якість публічної служби, іiі відповідність стандартам демократичної правової держави. Своєю чергою еволюція соціально-правових і політичних засад публічної служби в нашій державі вимагає фундаментальних змін у сфері етики поведінки відповідних суб’єктів, що обумовлює актуальність обраної теми дослідження.

Аналіз останніх досліджень і публікацій. Значення та зміст категорій «етика», «етична поведінка», а також правові засади функціонування сучасної публічної (державної) служби, принципи діяльності відповідних суб'єктів розглядалися у наукових працях Ю. Битяка, В. Бігуна, Ю. Буланової, А. Войтенка, В. Якобчук, Н. Пугачової, С. Жукова, Т. Коломоєць, О.Самойленко [2-8] тощо. Але, попри вагомий внесок наукової спільноти в розвиток дослідження цього питання, зміст та ефективність практичного втілення принципу «етична поведінка суб’ єктів публічної служби» не можна вважати остаточно з'ясованими.

Метою статті є отримання нових наукових результатів у вигляді обгрунтованих висновків та пропозицій щодо розв'язання актуальних теоретично-прикладних та правових проблем визначення принципу та правил етичної поведінки в діяльності суб’єктів публічної служби в Україні.

Матеріали та методи. Емпіричною базою дослідження стали правові акти законодавства України та деяких країн світу (США, Французької Республіки), праці науковців у галузі адміністративного права. Завдяки поєднанню загальнонаукових і спеціальних методів пізнання, зокрема діалектичного, формально-юридичного, порівняльного аналізу та синтезу, вдалося опрацювати зазначений емпіричний матеріал та отримати власні наукові висновки, що корелюються з метою статті.

Результати дослідження. Категорія «етична поведінка» має філософські витоки та разом 3 поняттям «доброчесність» сформована поза межами юриспруденції. В Україні ця категорія як явище, поняття i загалом дискурс актуалізується у правовому вимірі після подій 
2013-2014 pр., з акцентом на етичному вимірі соціальних перетворень як у державних інституціях, так й у суспільстві загалом.

Одним 3 основних обов'язків державного службовця згідно із Законом України «Про державну службу» (ст. 4) $є$ дотримання принципів державної служби та правил етичної поведінки. Водночас у ч. 3 ст. 3 закону прописано, що сфера його дії не поширюється на низку інших суб'єктів публічної служби, зокрема на посадових осіб місцевого самоврядування; військовослужбовців Збройних Сил України та інших військових формувань, прокурорів, поліцейських тощо. Особливості проходження служби та діяльності цих посадових осіб мають бути врегульовані іншими законодавчими актами. Здавалося б, Закон України «Про службу в органах місцевого самоврядування» багато в чому $є$ фактичним віддзеркаленням Закону України «Про державну службу», проте серед основних принципів служби в органах місцевого самоврядування (ст. 4) немає жодного згадування про принцип етичної поведінки [9].

У Законах України «Про Національну поліцію» та «Про Дисциплінарний статут Національної поліції України» етична поведінка також конкретно не зазначена серед принципів діяльності поліцейських, але їі зміст опосередковано випливає 3 нормативно закріпленого у ст. 64 Закону «Про Національну поліцію» (текст присяги поліцейських) [10]. У Законі України «Про прокуратуру» прописано, що прокурор повинен неухильно дотримуватись вимог професійної етики та поведінки, однак поняття та зміст цієї категорії законодавчо не визначений [11].

У ст. 38 Закону України «Про запобігання корупції» вказано, що особи, зазначені в п. 1, підпункті «а» п. 2 ч. 1 ст. 3 цього закону, «під час виконання своїх службових повноважень зобов'язані неухильно додержуватися вимог закону та загальновизнаних етичних норм поведінки, бути ввічливими у стосунках з громадянами, керівниками, колегами й підлеглими». Законодавець встановлює, що загальні вимоги до поведінки таких осіб, які окреслено у зазначеному законодавчому акті, мають складати правову основу для кодексів чи стандартів професійної етики суб’ єктів публічної служби, «якими вони зобов’язані керуватися під час виконання своїх службових чи представницьких повноважень. Загальні правила етичної поведінки державних службовців та посадових осіб місцевого самоврядування має затверджувати центральний орган виконавчої влади, що забезпечує формування та реалізує державну політику у сфері державної служби. Державні органи, органи місцевого самоврядування за необхідності розробляють та забезпечують виконання галузевих кодексів чи стандартів етичної поведінки їхніх працівників, а також інших осіб, уповноважених на виконання функцій держави або місцевого самоврядування, прирівняних до них осіб, які здійснюють діяльність у сфері їхнього управління» [12]. Тож можна констатувати, що нормативне закріплення етичних норм для різних 
категорій суб’єктів публічної служби в Україні передусім відбувається на підзаконному рівні, а також має галузевий характер.

У США етичні вимоги та обмеження, що стосуються державних службовців, здебільшого містяться у ст.ст. 202-209 Розділу 18 («Злочини та кримінальне судочинство») Кодексу США (цей правовий акт має зведену кодифікацію федерального законодавства Сполучених Штатів. - прим. авт.) й у Загальних стандартах поведінки працівників виконавчої влади 5 C.F.R § $2635.101(b) .14$ загальних принципів етичної поведінки (5 C.F.R § 2635.101 (b) стосуються кожного працівника державної служби і можуть утворювати основу для інших стандартів. У перших загальних принципах проголошується, що: 1) державна служба - це суспільна довіра, яка вимагає від посадовців відданості Конституції, законам та етичним принципам, які ставляться вище приватної вигоди; 2) працівники не повинні мати фінансових інтересів, що суперечать сумлінному виконанню посадових обов'язків тощо. Крім того, є такі цікаві принципи, як-от: 6) посадовці не повинні свідомо брати несанкціоновані зобов'язання чи робити обіцянки, які претендують на зобов'язання уряду; 14) посадовці повинні намагатися уникати будь-яких дій, що можуть створити уявлення про нібито порушення 3 їхнього боку закону або етичних норм, викладених у цьому правовому акті. Оцінювання конкретних обставин, що здатні створити таке уявлення, визначається 3 огляду пересічної розумної людини, якій відомо про такі факти. Цей документ містить лише узагальнений короткий зміст основних принципів, проте для ретельного аналізу правової ситуації необхідно посилатися на конкретні (спеціальні) закони, в яких загальногалузеві принципи доповнюються конкретними правилами, що стосуються певних категорій службовців публічного чи приватного сектору управління. Якщо за визначення правомірності чи відповідності поведінки державного службовця етичним нормам ситуація не охоплюється стандартами, викладеними в конкретних правових нормах, варто застосовувати загальні принципи, закріплені в документі 5 C.F.R § 2635.101 (b) [13]. Отже, у правовому визначенні етичності представників держави у США спостерігається певний дуалізм - діють загальні принципи (на федеральному законодавчому рівні) та конкретні чи спеціальні (на рівні інших федеральних законів чи правових актів штатів) правила етичної поведінки. Чи можна вважати це корисним прикладом та розглядати доцільність вибудовування подібної ієрархії правових норм (принципів та правил етичної поведінки для суб'єктів публічної служби) в Україні? Можливо.

Загальні правила етичної поведінки державних службовців і посадових осіб місцевого самоврядування в Україні (затверджені Наказом Національного агентства України з питань державної служби від 05.08.2016 № 158) є узагальненням стандартів етичної поведінки державних службовців і посадових осіб місцевого самоврядування, якими вони зобов'язані керуватися під час виконання своїх посадових 
обов'язків. У цих Правилах зазначено: «поведінка державних службовців і посадових осіб місцевого самоврядування має забезпечувати довіру суспільства до державної служби та служби в органах місцевого самоврядування. Етична поведінка державних службовців і посадових осіб місцевого самоврядування грунтується на принципах державної служби та служби в органах місцевого самоврядування, визначених Законами України «Про державну службу» і «Про службу в органах місцевого самоврядування», а також на загальних вимогах до поведінки цих осіб, що прописані в Законі України «Про запобігання корупції» [14]. Особливо варто звернути увагу на п. 2 розд. I, в якому зазначено, що «у цих Загальних правилах терміни вживаються у значеннях, встановлених Законами України «Про державну службу», «Про службу в органах місцевого самоврядування» та «Про запобігання корупції» [14]. Проте в цих законодавчих актах немає належного ладу щодо визначення поняття принципу етичної поведінки.

Відсутність чіткої дефініції термінів і «розмитість» понять та змісту одного 3 вихідних принципів діяльності суб’єктів публічної служби, різноманітність видів й проявів цієї служби змушує вивчати вітчизняне законодавство та шукати відповідь у різних нормативноправових актах. Але й у цьому разі ми стикаємося з проблемою браку уніфікованого підходу щодо розуміння принципу та змістовного наповнення правил етичної поведінки в діяльності різних суб’єктів публічної служби.

Наприклад, Загальні правила етичної поведінки державних службовців і посадових осіб місцевого самоврядування мають такі основні розділи: загальні обов'язки зазначених категорій осіб; умови та обмеження щодо використання службового становища; застосування ресурсів держави та територіальної громади; використання та обмін інформацією [14]. Водночас Правила етичної поведінки поліцейських (затверджено Наказом МВС України від 09.11.2016 № 1179), крім загальних положень, у яких дублюються принципи діяльності поліції, що наведені у Законі України «Про Національну поліцію», визначають ще основні вимоги до поведінки поліцейського під час виконання службових обов'язків; поводження поліції із затриманою особою; вимоги та умови взаємодії 3 громадськістю та іншими державними органами; обов'язки та контрольні повноваження керівників поліції за дотриманням етики підлеглими працівниками [15]. Аналогічно до приведених правових актів основні принципи професійної етики та вимоги до професійної поведінки прокурорів прописані в Кодексі професійної етики та поведінки прокурорів (затверджено Всеукраїнською конференцією прокурорів від 27.04.2017р.), стосовно суддів у Кодексі суддівської етики (затверджено ХІ черговим з'їздом суддів України від 22.02.2013 р.). Крім цього, можна навести ще багато прикладів правил етичної поведінки працівників окремих міністерств, державних служб тощо. 
На підставі аналізу всіх цих нормативно-правових актів доцільно зробити перший висновок - подібні Правила (Кодекси) $\epsilon$ узагальненим зібранням професійно-етичних вимог щодо правил поведінки відповідних суб'єктів публічної служби та спрямовані на забезпечення служіння ними суспільству шляхом забезпечення охорони, сприяння у реалізації прав і свобод людини на засадах етики та загальнолюдських цінностей. Певна частина цих норм містить дуже схожі для всіх вимоги (наприклад, «використання свого службового становища виключно для виконання своїх посадових обов’язків»), а деякі - уособлюють особливості специфіки тієї чи іншої діяльності (як-от вимоги до поводження поліції із затриманою особою тощо). Важливою відмінністю частини 3 переглянутих Кодексів чи Правил, наприклад, Кодексу професійної етики та поведінки прокурорів, Кодексу суддівської етики, Кодексу професійної етики працівників Національного антикорупційного бюро України є те, що вони містять положення та вимоги до поведінки суб’єктів публічної служби не лише під час виконання ними посадових обов'язків, а й у повсякденному житті. Так, «прокурору варто уникати особистих зв'язків, фінансових i ділових взаємовідносин, що можуть вплинути на неупередженість та об'єктивність виконання професійних обов'язків, скомпрометувати звання прокурора, не допускати дій, висловлювань і поведінки, які можуть зашкодити його репутації та авторитету прокуратури, викликати негативний суспільний резонанс» [16, с. 21]. Або «участь судді у соціальних мережах, інтернет-форумах і застосування ним інших форм спілкування в мережі Інтернет є допустимими, проте суддя може розміщувати, коментувати лише ту інформацію, використання якої не завдає шкоди авторитету судді та судової влади» $[17$, с. 20] тощо. На підставі цього доходимо другого важливого висновку - положення етичних Кодексів чи Правил етичної поведінки повинні також включати вимоги, які б регламентували поведінку суб'єкта публічної служби у позаробочий час у межах мінімального втручання в його особисте (приватне) життя та абсолютного невтручання у сферу реалізації права на свободу совісті, особистих переконань і світогляду. До речі, для деяких посадовців США $є$ певні обмеження навіть протягом перших двох років після звільнення з державної служби [13, с. 7].

$€$ думка, що етичні норми $€$ сугубо внутрішніми для певного колективу, вони не нав'язуються зовні ані законом, ані розпорядженнями начальства. Постає питання: чи відповідають вони вимозі «публічні цінності завжди переважають над індивідуальними інтересами», чи ні [18]. Це може бути актуальним для корпоративних етичних норм. Але подібна дилема де-юре не може виникати у діяльності суб'єктів публічної служби. У коментарі до Кодексу професійної етики працівників НАБУ прописано, що «цей документ $\epsilon$ підзаконним нормативним актом, отже, його положення не можуть 
суперечити положенням чинного законодавства України. Водночас як акт, що встановлює морально-етичні вимоги, він має специфічну сферу правового регулювання та має застосовуватися у тих ситуаціях, які не отримали відповідної законодавчої регламентації» [19, с. 10]. Натомість у ст. 4 Кодексу суддівської етики наголошено, що «порушення правил етичної поведінки, встановлених цим Кодексом, не можуть самі по собі застосовуватися як підстави для притягнення суддів до дисциплінарної відповідальності та визначати ступінь їх вини» [17]. Відповідно до ст.ст. 32 та 33 Кодексу професійної етики та поведінки прокурорів, «оцінка дотримання норм професійної етики та поведінки прокурора може проводитися під час дисциплінарного провадження та надаватися у разі розв’язання питань щодо підвищення по службі, присвоєння класного чину, підготовки характеристик і рекомендацій. Проте їхнє порушення тягне за собою відповідальність, встановлену законом» [16]. Тож виникає цілком слушне запитання: «Для кого існують ці кодекси та/чи правила? Для службовців чи для системи, яка їх контролює?».

Варто підкреслити, що багато вимог, заборон чи обмежень, які містяться в Кодексах чи Правилах етичної поведінки, насамперед визначені у Законі України «Про запобігання корупції» та інших профільних (спеціальних) законах. Звичайно, що підзаконні нормативноправові акти не можуть їм суперечити, а покликані лише деталізувати застосування законодавчих норм. Тож ці Кодекси чи Правила професійної етики передусім $є$ дієвим інструментом для персоналу суб'єктів публічної служби, а також мають сприяти поінформованості широкого загалу про особливості роботи цих суб'єктів. Вони акумулюють загальноправові принципи державного управління, найвищі стандарти поведінки, професіоналізму та дисципліни осіб, наділених певним обсягом владних повноважень, акцентуючи увагу на особливостях оптимального урегулювання типових для кожної сфери державної діяльності конфліктів публічних і приватних інтересів. Такі правові акти мають бути дієвим інструментом комунікації з суспільством та водночас формувати сталу організаційну культуру відносин всередині державної інституції.

Для порівняння, Кодекс етики національної поліції та національної жандармерії Французької Республіки 2014 р. є не тільки узагальненим зібранням професійно-етичних вимог щодо правил поведінки поліцейських та жандармів, а й інструментом гарантування прав цих представників публічної служби, а також їх захисту. Етичні норми, що прописані в цьому Кодексі, випливають з Конституції, міжнародних договорів, зокрема Свропейської конвенції про захист прав людини та основоположних свобод, загальних принципів права та законів і норм Республіки. Вони визначають обов'язки правоохоронців щодо виконання своїх завдань під час служби або поза нею і застосовуються без шкоди для статутних правил та інших зобов'язань, яких ці посадові особи матимуть дотримуватися. Етичні норми є предметом 
початкової та постійної підготовки поліцейських і жандармів, щоб вони могли бездоганно виконувати свої обов'язки. Зазначений французький правовий акт 3 урахуванням принципу ієрархічності урегульовує відносини між керівниками та підлеглими, згадуючи водночас про деякі важливі зобов’язання держави в особі керівництва перед персоналом поліції чи жандармерії, зокрема функціональний захист. У ст. R. 434-7 цього Кодексу зазначено, що держава захищає поліцейського або жандарма, а також у межах, встановлених законом, його близьких осіб від погроз, насильства, нападів, образ, наклепів, жертвою яких він може стати через виконання своїх функціональних обов’язків. Держава надає поліцейському чи жандарму також правовий захист у разі судового розгляду фактів, що не мають характеру особистої провини [20].

Висновки. Під принщипом етичної поведінки пропонується розуміти свідоме дотримання суб’єктами публічної служби основоположних принципів верховенства права, поваги до прав і свобод людини, політичної нейтральності, справедливості, неупередженості та рівності тощо, правових, соціальних і корпоративних норм, професійноетичних вимог, керуючись ними під час здійснення певних дій (або за утримання від їхнього виконання) та прийняття рішень як під час, так і поза виконання службових обов'язків, ставлячи публічний інтерес та авторитет служби понад власної вигоди, усвідомлюючи високий ступінь довіри суспільства та власної відповідальності за свої вчинки перед цим суспільством.

Своєю чергою правилами етичної поведінки в діяльності суб’єктів публічної служби $є$ формально визначені та закріплені у правових актах найвищі стандарти поведінки, професіоналізму та дисципліни осіб, наділених певним обсягом владних повноважень, що мають галузеву спеціалізацію та звертають увагу на особливостях оптимального урегулювання типових для кожної сфери державної діяльності конфліктів публічних і приватних інтересів. На відміну від правил дотримання принципу етичної поведінки у діяльності суб’єктів публічної служби грунтується на внутрішньому переконанні конкретної людини і залежить від їі моральності та доброчесності.

Немає сенсу щодо наявності єдиного правового акта, який би об’єднував етичні норми для всіх видів і проявів публічної служби, оскільки кожен з них має власні особливості втілення цих норм на певному професійному рівні. Водночас у профільних законах варто провести уніфікацію основоположних принципів публічної служби, що мають бути в загальних положеннях галузевих Правил та Кодексів етичної поведінки разом зі спеціальними нормами, які уособлюватимуть специфіку тієї чи іншої публічної діяльності.

Положення етичних Кодексів чи Правил етичної поведінки повинні також мати вимоги, які б регламентували поведінку суб'єкта публічної служби в позаробочий час у межах мінімального втручання в його особисте (приватне) життя та абсолютного невтручання у сферу реалізації права на свободу совісті, особистих переконань і світогляду. 
Враховуючи зазначені узагальнення та пропозиції, в подальших наукових розвідках планується детальніше проаналізувати положення Правил етичної поведінки поліцейських 3 метою удосконалення їхнього правового регулювання.

\section{СПИСОК ВИКОРИСТАНИХ ДЖЕРЕ}

1. Кодекс адміністративного судочинства України: Закон України від 06.07.2005 р. № 2747-IV. Редакція від 26.05.2021. URL: https://zakon.rada.gov.ua/laws/show/2747-15\#Text (дата звернення: 06.06.2021).

2. Битяк Ю. П. Державна служба в Україні: проблеми становлення, розвитку та функціонування: дис. ... д-ра юрид. наук: 12.00.07. Нац. юрид. академія України імені Ярослава Мудрого. Харків, 2006. 390 с.

3. Бігун В. С. Доброчесність як юридичний термін i сенс. Часопис Київського університету права. 2019. № 1. С. 25-29.

4. Буланова Ю. М. Зарубіжні та міжнародні стандарти дотримання етичних норм службової діяльності. Правові новели. Науковий юридичний журнал. 2020. № 10. C. 147-153. DOI: 10.32847/ ln.2020.10.21.

5. Войтенко А. Б., Якобчук В. П., Пугачова Н. С. Професійна етика державного службовця в контексті ефективності публічного управління. Державне управління: удосконалення та розвиток. 2020. № 2. DOI: 10.32702/2307-2156-2020.2.36.

6. Жуков С. В. Феномен доброчесності: до питання методології дослідження. Науковий вісник публічного та приватного права. Вип. 5. Т. 1. 2018. С. 23-26.

7. Коломоєць Т. О. Службове право - це самостійна галузь права чи елементи системи адміністративного права? Питання адміністративного права. Кн. 2. Харків: Оберіг, 2018. С. 131-140.

8. Самойленко О. С. Етичні засади формування службового права. Юридичний часопис Національної академії внутрішніх справ. 2020. № 1 (19). C. 68-72. DOI: 10.33270/04201901.68.

9. Про державну службу: Закон України від 10.12.2015 № 889-VIII. Редакція від 06.03.2021. URL: https://zakon.rada.gov.ua/laws/show/ 88919\#Техt (дата звернення: 06.06.2021).

10. Про Національну поліцію: Закон України від 02.07.2015 № 580-VIII. Редакція від 23.04.2021. URL: https://zakon.rada.gov.ua/laws/show/58019\#Техt (дата звернення: 06.06.2021).

11. Про прокуратуру: Закон України від 14.10.2014 № 1697-VII. Редакція від 22.05.2021 URL: https://zakon.rada.gov.ua/laws/show/1697-18\#Tеxt (дата звернення: 06.06.2021).

12. Про запобігання корупції: Закон України від 14.10.2014 № 1700-VII. Редакція від 02.06.2021. URL: https://zakon.rada.gov.ua/laws/show/170018\#Техt (дата звернення: 06.06.2021).

13. The 14 General Principles of Ethical Conduct 5 C.F.R § 2635.101 (b). (n. d.). justice.gov. URL: https://www.justice.gov/archives/ncfs/page/file/761076/ download (дата звернення: 08.06.2021).

14. Про затвердження Загальних правил етичної поведінки державних службовців та посадових осіб місцевого самоврядування: Наказ Національного агентства України з питань державної служби від 05.08.2016 р. № 158. Дата оновлення: 04.06.2021. URL: https://zakon.rada.gov.ua/laws/ show/z1203-16\#Техt (дата звернення: 08.06.2021). 
15. Про затвердження Правил етичної поведінки поліцейських: Наказ МBC України від 09.11.2016 № 1179. URL: https://zakon.rada.gov.ua/laws/show/ z1576-16\#Text (дата звернення: 08.06.2021).

16. Кодекс професійної етики та поведінки прокурорів: затв. Рішенням Всеукраїнської конференції прокурорів від 27.04.2017. URL: https://zakon.rada.gov.ua/laws/show/n0001900-17\#Text (дата звернення: 08.06.2021).

17. Кодекс суддівської етики: затв. Рішенням ХІ чергового з’їзду суддів України від 22.02.2013. URL: https://zakon.rada.gov.ua/rada/show/ n0001415-13\#Text (дата звернення: 08.06.2021).

18. Прошко В. Принцип VI: Етична поведінка. Блогери за добре врядування: 18.03.2019. URL: https://bloggers4gg.org.ua/2019/03/princip-vi-etichna-povedinka/ (дата звернення: 09.06.2021).

19. Кодекс професійної етики працівників Національного антикорупційного бюро України. Національне антикорупційне бюро України. Київ. 64 с. URL: https://nabu.gov.ua/kodeks-profesiynoyi-etyky-pracivnykiv-nabu (дата звернення: 08.06.2021).

20. Code de déontologie de la police nationale et de la gendarmerie nationale. (2014). Le code de déontologie de la police et de la gendarmerie nationales est codifié au livre IV, titre 3 , chapitre 4 de la partie réglementaire du code de la sécurité intérieure. Il entre en vigueur le 1er janvier 2014. URL: https://www.interieur.gouv.fr/Le-ministere/Deontologie\#: :text=Code\%20de\% 20d\%C3\% A9ontologie\%20de\%20la, le\%201er\%20janvier\%202014 (дата звернення: 08.06.2021).

Стаття надійшла до редакиії 11.06.2021.

\section{service entities. \\ Veselov M., Yepryntsev P. Ethical norms in the activities of public}

Background. The choice of the topic of the article is dictated by the presence of significant theoretical problems and the need to improve the understanding and legal definition of the principle and rules of ethical behavior in the activities of public service entities in Ukraine.

The aim of the article is to obtain new scientific results in the form of substantiated conclusions and proposals for solving current theoretical, applied and legal problems of determining the principle and rules of ethical behavior in the activities of public service entities in Ukraine.

Materials and methods. The empirical basis of the study were legal acts of legislation of Ukraine and some other countries, scientific works of other scholars in the field of administrative law. Thanks to a combination of general scientific and special methods of cognition it was possible to process the specified empirical material and to receive own scientific conclusions.

Results. It is noted that there is no clear definition and common understanding of the concept of the principle of ethical conduct of public service entities in the Ukrainian legislation. It is stated that the normative consolidation of ethical norms for different categories of public service entities in Ukraine takes place mainly at the by-law level and has a sectoral nature. It is established that the terms «principle of ethical conduct» and «rules of ethical conduct» are interdependent concepts, but not identical. 
Conclusion. According to the results of the research, the author's vision is given to the concepts of "principle of ethical behavior» and «rules of ethical behavior». It is emphasized that the provisions of the Codes of Ethics or the Code of Ethics should also include requirements that would regulate the conduct of the public service entity in the off-hours. The necessity of unification of basic principles of public service in profile laws is substantiated, which should be reflected in general provisions of branch Rules and Codes of ethics together with special norms which will embody specificity of this or that public activity.

Keywords: public service, the subject of public service, principles of activity, ethical behavior, rules, norms.

\section{REFERENCES}

1. Kodeks administratyvnogo sudochynstva Ukrai'ny: Zakon Ukrai'ny vid 06.07.2005 r. № 2747-IV. Redakcija vid 26.05.2021 [Code of Administrative Procedure of Ukraine: Law of Ukraine of July 6, 2005 № 2747-IV. Edited from 26.05.2021]. Retrieved from https://zakon.rada.gov.ua/laws/show/2747-15\#Text (data zvernennja: 06.06.2021) [in Ukrainian].

2. Bytjak, Ju. P. (2006). Derzhavna sluzhba v Ukrai'ni: problemy stanovlennja, rozvytku ta funkcionuvannja: dys. ... d-ra juryd. nauk: 12.00.07 [Civil service in Ukraine: problems of formation, development and functioning: dis. ... Dr. of Jurid. Sciences: 12.00.07]. Nacional'na jurydychna akademija Ukrai'ny imeni Jaroslava Mudrogo. Harkiv [in Ukrainian].

3. Bigun, V. S. (2019). Dobrochesnist' jak jurydychnyj termin i sens [Virtue as a legal term and meaning]. Chasopys Kyi'vs'kogo universytetu prava - Journal of Kyiv University of Law, 1, 25-29 [in Ukrainian].

4. Bulanova, Ju. M. (2020). Zarubizhni ta mizhnarodni standarty dotrymannja etychnyh norm sluzhbovoi' dijal'nosti. Pravovi novely [Foreign and international standards of compliance with ethical norms of official activity. Legal short stories]. Naukovyj jurydychnyj zhurnal - Scientific legal journal, 10, 147-153. DOI: 10.32847/ $\ln$ 2020.10.21 [in Ukrainian].

5. Vojtenko, A. B., Jakobchuk, V. P., \& Pugachova N. S. (2020). Profesijna etyka derzhavnogo sluzhbovcja $\mathrm{V}$ konteksti efektyvnosti publichnogo upravlinnja [Professional ethics of a civil servant in the context of public administration efficiency]. Derzhavne upravlinnja: udoskonalennja ta rozvytok - Public administration: improvement and development, 2. DOI: 10.32702/2307-21562020.2.36 [in Ukrainian].

6. Zhukov, S. V. (2018). Fenomen dobrochesnosti: do pytannja metodologii' doslidzhennja [The phenomenon of virtue: to the question of research methodology]. Naukovyj visnyk publichnogo ta pryvatnogo prava - Scientific Bulletin of Public and Private Law, (Issue 5), (Vol. 1), (pp. 23-26) [in Ukrainian].

7. Kolomojec', T. O. (2018). Sluzhbove pravo - ce samostijna galuz' prava chy elementy systemy administratyvnogo prava? Pytannja administratyvnogo prava [Is service law an independent branch of law or elements of the system of administrative law? Issues of administrative law], (Vol. 2). Harkiv: Oberig, (pp. 131-140) [in Ukrainian].

8. Samojlenko, O. S. (2020). Etychni zasady formuvannja sluzhbovogo prava [Ethical principles of formation of service law]. Jurydychnyj chasopys Nacional'noi' akademii' vnutrishnih sprav - Legal Journal of the National Academy of Internal Affairs, 1 (19), 68-72. DOI: 10.33270/04201901.68 [in Ukrainian].

9. Pro derzhavnu sluzhbu: Zakon Ukrai'ny vid 10.12.2015 № 889-VIII. Redakcija vid 06.03.2021 [On civil service: Law of Ukraine of 10.12.2015 № 889-VIII. Edited on March 6, 2021]. Retrieved from https://zakon.rada.gov.ua/laws/show/889-19\#Text (data zvernennja: 06.06.2021) [in Ukrainian]. 
10. Pro Nacional'nu policiju: Zakon Ukrai'ny vid 02.07.2015 № 580-VIII. Redakcija vid 23.04.2021 [About the National Police: Law of Ukraine of 02.07.2015 № 580-VIII. Edited on April 23, 2021]. Retrieved from https://zakon.rada.gov.ua/laws/show/58019\#Text (data zvernennja: 06.06.2021) [in Ukrainian].

11. Pro prokuraturu: Zakon Ukrai'ny vid 14.10.2014 № 1697-VII. Redakcija vid 22.05.2021 [About the Prosecutor's Office: Law of Ukraine of October 14, 2014 № 1697-VII. Edited on 22.05.2021]. Retrieved from https://zakon.rada.gov.ua/ laws/show/1697-18\#Text (data zvernennja: 06.06.2021) [in Ukrainian].

12. Pro zapobigannja korupcii': Zakon Ukrai'ny vid 14.10.2014 № 1700-VII. Redakcija vid 02.06.2021 [On the prevention of corruption: Law of Ukraine of 14.10.2014 № 1700-VII. Edited from 02.06.2021]. Retrieved from https://zakon.rada.gov.ua/laws/ show/1700-18\#Text (data zvernennja: 06.06.2021) [in Ukrainian].

13. The 14 General Principles of Ethical Conduct 5 C.F.R § 2635.101 (b). (n. d.). justice.gov. Retrieved from https://www.justice.gov/archives/ncfs/page/file/761076/ download (data zvernennja: 08.06.2021) [in English].

14. Pro zatverdzhennja Zagal'nyh pravyl etychnoi' povedinky derzhavnyh sluzhbovciv ta posadovyh osib miscevogo samovrjaduvannja: Nakaz Nacional'nogo agentstva Ukrai'ny z pytan' derzhavnoi' sluzhby vid 05.08.2016 r. № 158. Data onovlennja: 04.06.2021. [On approval of the General rules of ethical conduct of civil servants and local government officials: Order of the National Agency of Ukraine on Civil Service issues of 05.08.2016 № 158. Date of update: 04.06.2021] Retrieved from https://zakon.rada.gov.ua/laws/show/z1203-16\#Text (data zvernennja: 08.06.2021) [in Ukrainian].

15. Pro zatverdzhennja Pravyl etychnoi' povedinky policejs'kyh: Nakaz MVS Ukrai'ny vid 09.11.2016 № 1179 [On approval of the Rules of ethical conduct of police officers: Order of the Ministry of Internal Affairs of Ukraine dated 09.11.2016 № 1179]. Retrieved from https://zakon.rada.gov.ua/laws/show/z1576-16\#Text (data zvernennja: 08.06.2021) [in Ukrainian].

16. Kodeks profesijnoi' etyky ta povedinky prokuroriv: zatv. Rishennjam Vseukrai'ns'koi' konferencii' prokuroriv vid 27.04.2017 [Code of professional ethics and conduct of prosecutors: approved by the Decision of the All-Ukrainian Conference of Prosecutors dated April 27, 2017]. Retrieved from https://zakon.rada.gov.ua/ laws/show/n0001900-17\#Text (data zvernennja: 08.06.2021) [in Ukrainian].

17. Kodeks suddivs'koi' etyky: zatv. Rishennjam XI chergovogo z'i'zdu suddiv Ukrai'ny vid 22.02.2013 [Code of Judicial Ethics: approved by the Decision of the XI regular congress of judges of Ukraine dated February 22, 2013]. . Retrieved from https://zakon.rada.gov.ua/rada/show/n0001415-13\#Text (data zvernennja: 08.06.2021) [in Ukrainian]..

18. Proshko, V. (2019). Pryncyp VI: Etychna povedinka. Blogery za dobre vrjaduvannja: 18.03.2019 [Principle VI: Ethical Behavior. Bloggers for good governance: March 18, 2019]. Retrieved from https://bloggers4gg.org.ua/2019/03/princip-vietichna-povedinka/ (data zvernennja: 09.06.2021) [in Ukrainian].

19. Kodeks profesijnoi' etyky pracivnykiv Nacional'nogo antykorupcijnogo bjuro Ukrai'ny [Code of professional ethics of employees]. Nacional'ne antykorupcijne bjuro Ukrai'ny. National Anti-Corruption Bureau of Ukraine. Kyi'v. Retrieved from https://nabu.gov.ua/kodeks-profesiynoyi-etyky-pracivnykiv-nabu (data zvernennja: 08.06.2021) [in Ukrainian].

20. Code de déontologie de la police nationale et de la gendarmerie nationale. (2014). Le code de déontologie de la police et de la gendarmerie nationales est codifié au livre IV, titre 3, chapitre 4 de la partie réglementaire du code de la sécurité intérieure. Il entre en vigueur le 1er janvier 2014. Retrieved from https://www.interieur.gouv.fr/ Leministere/Deontologie\#: :text=Code\%20de\%20d\%C3\%A9ontologie\%20de\%20la,le\% 201er\%20janvier\%202014 (data zvernennja: 08.06.2021) [in France]. 